\title{
The Influence of Different Digital Content Marketing on Consumer Engagement in The Tourism Sector
}

\author{
Asmara Khairani ${ }^{*}$, Ira Fachira ${ }^{2}$ \\ 1,2 School of Business and Management, Bandung Institute of Technology, Bandung, Indonesia
}

\section{A R T I C L E I N F O}

\section{Article history:}

Received July 19, 2021

Revised July 20, 2021

Accepted August 10, 2021

Available online August 25, 2021

Keywords:

Digital Content Marketing Consumer Engagement, Social Media Marketing, Tourism

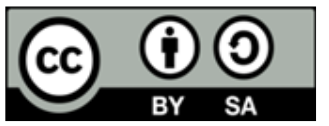

This is an open access article under the CC BY-SA license.

Copyright () 2021 by Author. Published by Universitas Pendidikan Ganesha.

\begin{abstract}
A B S T R A C T
Social media marketing and change in consumer behavior when traveling in the digital era, present opportunities for tourism sector. Aligned with these facts, digital content marketing becomes more important in improving consumer engagement through social media. Content marketing currently has shifted to a digital world known as digital content marketing. The more people view content on social media, the more it affects consumer engagement. Thus, a study is required to determine how social media marketing can help promote Indonesian locations, especially when Indonesia is trying to cope with many losses due to the pandemic. This study used content analysis to identify the differences between digital content marketing of the travel content by identifying 150 informative and persuasive content and analyzing consumer engagement on the social media platform Instagram. The results show that persuasive content has the most impact on consumer engagement. Also, this study can contribute to digital content marketing and consumer engagement concept literature in the tourism context. In addition, it can be a reference for company in the tourism sector to market their content by paying more attention to the type of content that is of interest to the public to attract public interest in the intended destination (destination branding).
\end{abstract}

\section{INTRODUCTION}

Today, billions of people have used internet digital communication technology, social media, mobile applications, which cannot be separate from their daily lives. Companies can achieve their marketing objectives at a low cost by using digital and social media marketing (Algharabat et al., 2020). DCM refers to activities carried out via digital (online) platforms such as the company website, virtual communities, blogs, vlogs, social media, and mobile apps (Eigenraam et al., 2021; Lujja \& Özata, 2017). Consumers are becoming increasingly skeptical of advertising and other traditional marketing communications, paving the way for Digital Content Marketing to thrive (Dabbous \& Barakat, 2020; Kim \& Kim, 2020). Digital Content Marketing (DCM) is based on a genuine desire to add value to consumers' lives in a variety of ways in order to increase customer engagement (Bianchi \& Andrews, 2018; Zeng \& Gerritsen, 2014). Although DCM research is relatively new in this era, some progress has been made in determining DCM's importance in driving consumer behavior (Alibage \& Jetter, 2017; Alvarez-Milán et al., 2018).

The benefit of DCM is that it reaches a larger audience with lower marketing costs, eliminating the need for advertising or personal selling activities (Bu et al., 2021; Dwivedi et al., 2021). Consequently, while DCM remains committed to increasing long-term sales, the company prioritizes consumer engagement and trust (Barger et al., 2016). Digital marketer expects DCM to influence consumers to buy or use services consistently because traditional advertisements about products and promotion of services alone no longer appeal to consumers today (Fernandes \& Moreira, 2019; Taiminen \& Ranaweera, 2019). On the other hand, displaying content marketing is cheaper than advertising in various media, making many digital marketers from multiple brands in Indonesia believe that content marketing is an exciting opportunity to explore digital marketing. Customer engagement is linked to many important indicators of brand performance, including sales growth, client participation in product development, customer feedback, and references (Dinçer, 2018; Li, 2021; Pektas \& Hassan, 2020). DCM for customer engagement is about being relevant, where a brand must fulfil its needs by providing value. It means focusing entirely on the wants, emotions, likes, and how the audience behaves. DCM has gotten a lot of attention in recent years because it is such an important part of digital marketing (Harrigan et al., 2017). Nevertheless, there is no unified and widely 
accepted definition of DCM in academia concept (Rietveld et al., 2020). Many businesses are getting involved in a marketing activity called content marketing.

Digital content marketing can serve many purposes, but customer engagement is always an intermediary in developing what kind of content plan to create. Customer engagement has increased brand loyalty, trust, and evaluations (So et al., 2014). Social media facilitate the engagement of customers, but neither of these is well investigated within the context of tourism. The tourism sector, especially Facebook and Twitter, is highly used in social media (Brodie et al., 2011; Matikiti-Manyevere \& Kruger, 2019). Instagram users upload 42 million photos and like posts 1.65 billion times per day, indicating that social media is becoming more popular (Filieri et al., 2021). The current increase in the number of Instagram users is an excellent opportunity for organizations to carry out promotional activities, including currently, the government is trying to promote Indonesia through various types of content, such as photos and videos. During the Covid-19 pandemic, Indonesia experienced a lack of trust destination from local and foreign tourists. The Ministry of Tourism and Creative Economic expect digital platforms to attract tourists' trust effectively. The keys to the recovery of the tourism industry are the winning of trust and confidence. The tourism industry is one of the major sectors whose digitalization has been widely accepted, and it requires interaction to provide a better tourism experience. Therefore, it is important to use information technology effectively (Dolan et al., 2019). In the digital media era, there has been a shift in consumer behavior in the tourism industry. The technological evolution of social media platforms has allowed people to find out reviews and access more content. Of course, it shifts consumer behavior (Dolan et al., 2016). Not only consumer behavior but the consumer decision-making process in the tourism industry has also changed.

Now consumers have even more information available with just one click. Since tourism is an information-intensive industry, social media is highly relevant to this industry. Social media frequently facilitates customer engagement, but none of these trends has been thoroughly researched, and there is a need for a recommendation for tourism organizations. Examples of social media tourism sites include TripAdvisor, Booking.com, Airbnb, and Lonely Planet (Algharabat et al., 2020; Wang \& McCarthy, 2021). Now, customers can leave comments, rate, share, and even create online content that appears in search engine results. The importance of social media in the tourism industry as a tool for customer engagement cannot be overstated (Kannan, 2017; Shin \& Back, 2020). Customer engagement is facilitated by social networking, but none of these phenomena has been thoroughly researched in tourism (Gon, 2021; Moran et al., 2019). Instagram as the popular social media might be useful to solve the Ministry of tourism problem through digital content marketing. Previous studies explain the various fields studied. This study aims to identify the differences between digital content marketing and consumer engagement on the social media platform Instagram. The scope of this research consists of limitations and assumptions. The limitations used in this study are the research objects are three Instagram accounts that display content about tourism so it cannot be used as a benchmark for industries other than tourism. Second, the data used are posts uploaded by three Instagram accounts with tourism content from February 2021 to May 2021. Last, the data used are posts in the form of images without using posts in videos. The assumptions used in this study are: there is no consideration regarding the content of comments and only see the number of comments listed on the Instagram account page. There is no consideration of past Instagram posting times, impacting the number of likes and comments.

\section{METHODS}

In general, content analysis is defined as the systematic coding of qualitative or quantitative data based on specific themes or categories (Islam et al., 2019; Shahbaznezhad et al., 2021). Although social media tourist research is still in its infancy, scientists generally recognize that social media positively affects the tourism sector (Coelho et al., 2016; Du Plessis, 2017). As well as the importance of social networks in customer engagement (Lee et al., 2018). This study will gather data from various travel content and official accounts of the Republic of Indonesia Ministry of Tourism and Creative Economy. This study includes the Instagram feed content, which shows the number of comments and likes in the Instagram feed. The data recorded from this account comes from highlighting the latest posts on each Instagram feed. Since Instagram provides real-time photo and video sharing, the researchers decided to choose a travel period until 10 May 2021. Then the content is categorized by content type according to each element.

The research focuses on uploaded contents from Instagram accounts pictures about tourism destinations and the account. It can be a personal / business account. Amount followers are taken into consideration as a criterion analyzed account selection. The researcher collects data using Python Anaconda V3 to pull data on the Instagram feed. The steps taken are to pull image data, identify caption and hashtags. Then the researcher analyzed the last position of 10 May 2021 and took 100 recent photos uploaded from each account. The content analysis does not carry out sentiment analysis because it is only 
a picture. Therefore, to determine the level of engagement from each type of content, it can be identified based on the elements. After collecting data, the researcher sorted the data to separate the photo and video data. The researcher found that video is not primarily being posted, so that this study will analyze photo content. The consideration is that content in videos, giveaways, photo challenges, endorsements, hotel accommodation collaborations, big day celebrations, animal pictures, and other posts concerning the personal account owner is not included in the identification process.

An empirical study of social media content, measuring significant engagement on social media platforms through comments and likes (Moran et al., 2019). Based on this, the researchers chose the Instagram feed as the content to be analyzed because the Instagram feed has quite a lot of likes and comments, so it can also be measured how big the engagement is. By sorting the existing content into two types (informative and persuasive), it can be seen which type of content has the most significant engagement. The content selected by the researcher comes from 3 accounts which will be explained in the section on population and sampling. The researcher decided to analyze the image/photo because only a few accounts posted the video. Moreover, Moran et al. state in 2019 that photographic posts are more effective than video posts. Several content elements will be used from the uploaded photos to divide DCM into three types, which already describe the types of informative and persuasive content.

As a target, the number of posts from three different DCM will be the population for the qualitativecontent study. The researcher collected three of the most famous accounts and has the most followers. In addition, the consideration of choosing these accounts is based on content that represents Indonesia and has become a lot of references for the travel community. Population data collection has been taken for 100 recent posts of each Instagram account with the last position, 10 May 2021. It considering that travel permits have begun to be allowed by the government with several requirements and implementation of health protocols. The next step is the calculation of the number of samples with a sufficient population size for this study. The sampling method is used to obtain accurate data from the sample. The most suitable sampling technique for this data collection method is purposive sampling. A purposive sample, a nonprobability sample technique that uses specific selection criteria to complement the purpose of the study before elements are used, was used to identify, and select data from social media. (Daniel 2012:87). Purposive sampling is sampling following the strong considerations of the researcher. The sample data source of this research is an image from each account of the content creator.

\section{RESULTS AND DISCUSSIONS}

\section{Results}

Corbin and Strauss, 1990 present an overarching, open coding, axial coding, and selective coding approach with manual coding. When the text data is broken into discrete parts, open coding is provided. Then the axial coding is the connection between the codes created by the researcher. Finally, selective coding is provided when all analysis codes are linked by the main category, and the essence of the research is defined. The final section must review the focus of the paper and highlight key findings and additional comments or wider implications for the development of theoretical and/or professional knowledge. Some examples of the content contain informative and persuasive elements seen from the elements and captions made by the Instagram account. The analysis is carried out only on image content taken in Indonesia. Only a small amount of video content was uploaded from the analysis results, so the researchers would only focus on content in photos. The total content analyzed is 150 contents. The @indonesiatravel account has the most followers among @folkindonesia and @exploreindonesia. However, the analysis was continued by analyzing other Instagram elements, which is the number of likes and comments.

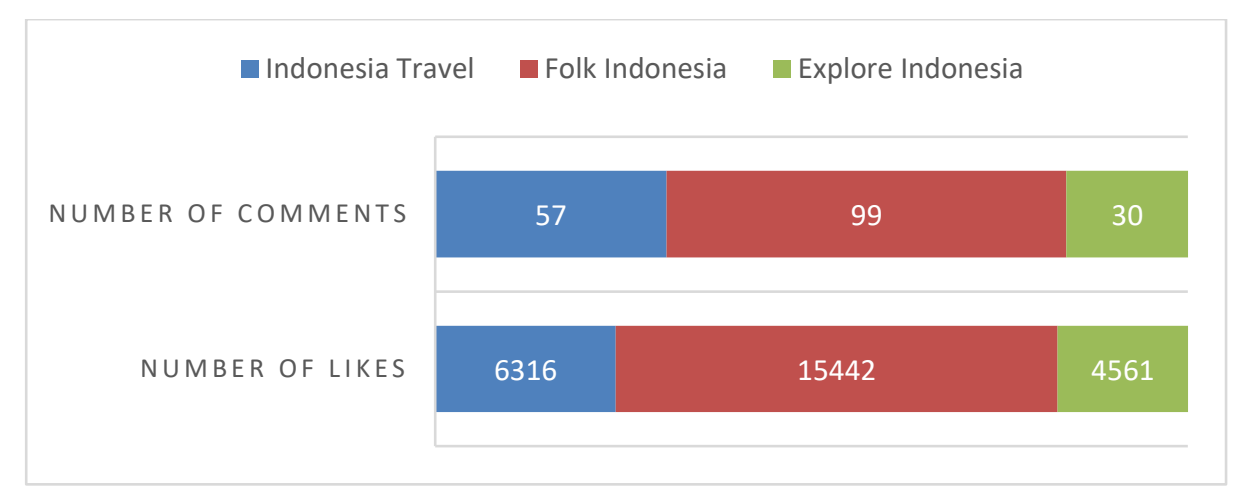

Figure 1. Average Number of Like and Comment 
In Figure 1, the highest average number of likes and comments is on the Folk Indonesia's account, followed by the Indonesia Travel, and Explore Indonesia. In this study, comments on each content were not analyzed by sentiment analysis. It determines the level of engagement of each type of content, and the analysis was limited to the number of comments.

\section{Analyzing DCM Image Type by The Caption}

There are several stages in the caption analysis process which is done manually coding. First, find the keywords from the analyzed captions, then categorize them by determining the DCM type. The categorization process is conducted by matching the definition of each type of informative and persuasive content. Figure 2 is a flowchart to determine the type of DCM based on the caption of each photo.
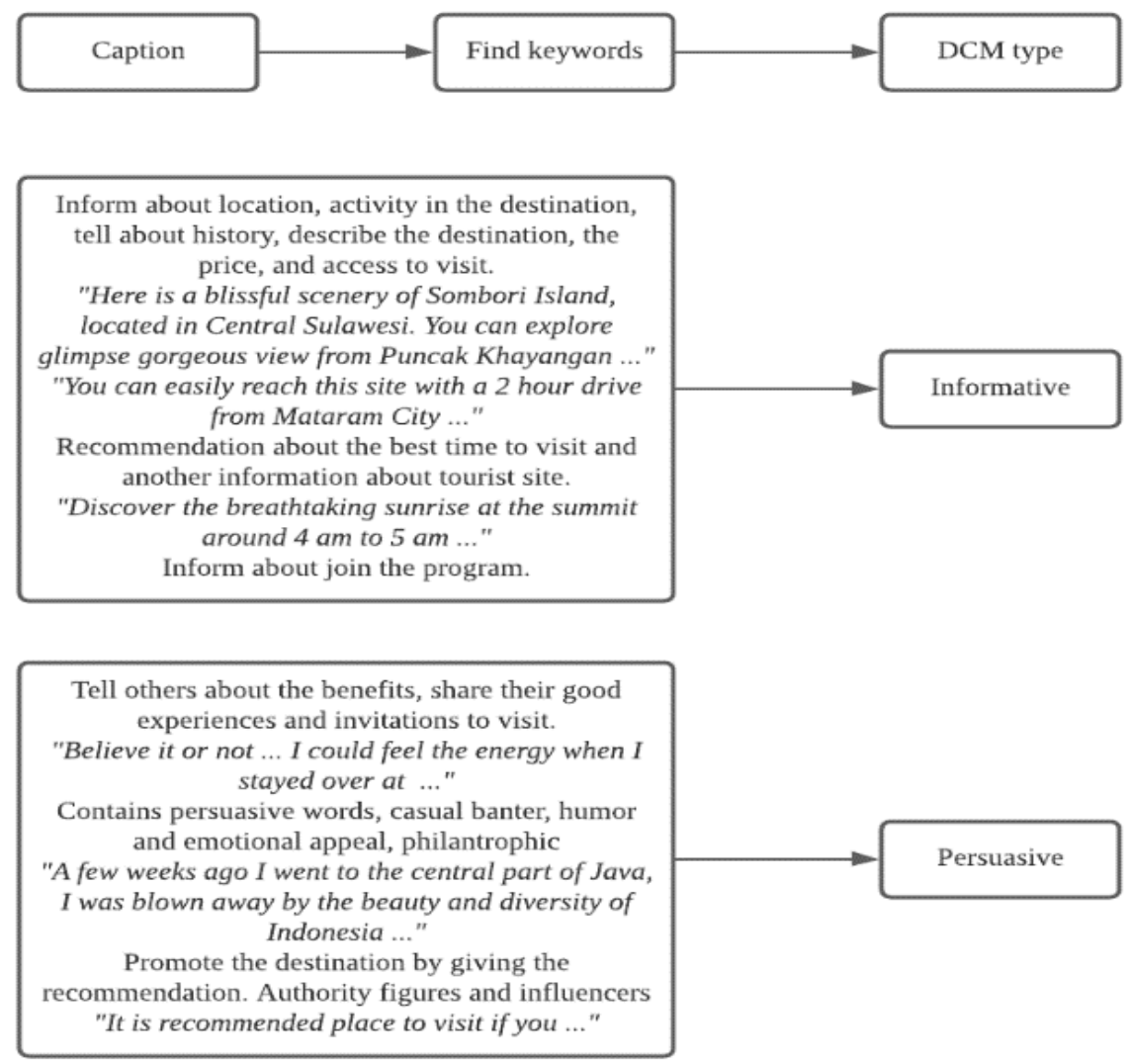

Figure 2. Flowchart for Analyzing DCM Type by The Caption

Table 1 show summary findings from the Instagram element and the percentage of popularity and level of engagement of each account.

Table 1. Summary Findings Number of Likes, Comments, and Popularity

\begin{tabular}{lccc}
\hline & Indonesia Travel & Folk Indonesia & Explore Indonesia \\
\hline Number of Likes & 315,783 & 772,081 & 228,062 \\
Comments & 2873 & 4959 & 1509 \\
Popularity (\%) & $2,1 \%$ & $4,5 \%$ & $3,6 \%$ \\
Engagement Rate & Average & High & Average \\
\hline
\end{tabular}

Based on the Table 1, the engagement level of each account is obtained, which shows how much influence popularity has on the engagement of each Instagram account. First, the data above is taken based on the content that gets the most likes and comments. Then the engagement score is calculated using a formula (Alvarez-Milán et al., 2018), who said the number of likes is "online social currency". The results of the engagement calculation show that@folkindonesia has higher engagement than @indtravel and @exploreindonesia. Even the official account of Kemenparekraf RI (@indtravel) has the most followers, but from the analysis, it turns out that Folk Indonesia has the highest engagement. 


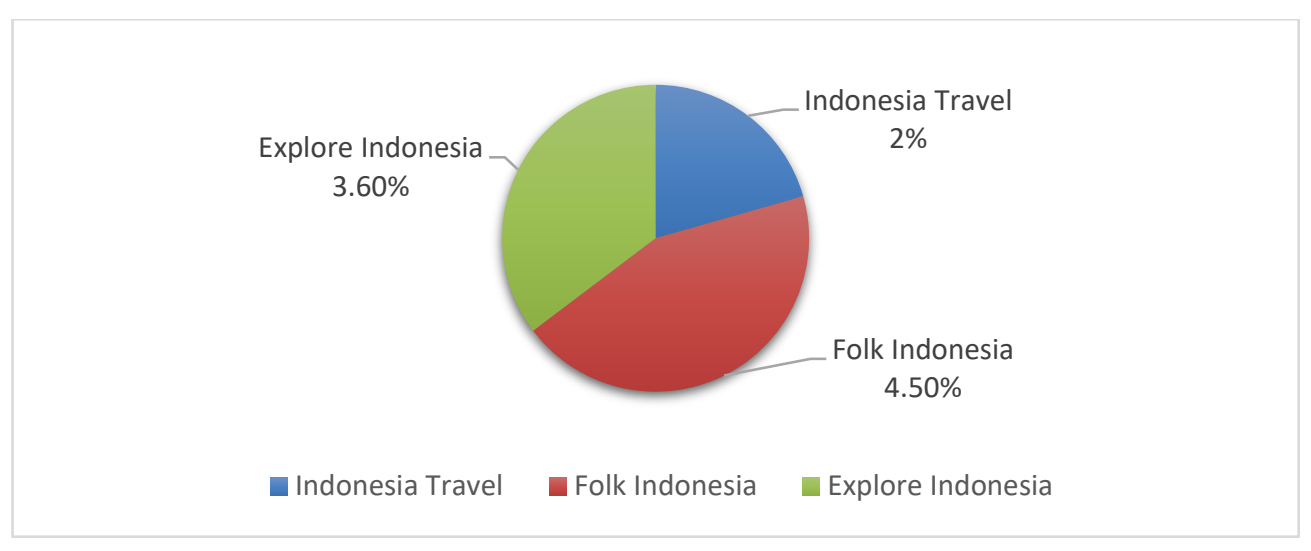

Figure 3. Popularity (Account Ratio \%)

From Figure 3, it can analyze that Folk Indonesia has the highest engagement among the other two Instagram accounts. According to the findings of the content analysis, persuasive content has higher engagement than informative content. The popularity factor of the Instagram account is also a consideration to determine whether the content has a high engagement or not. It can see that @folkindonesia has the highest engagement rate with content that is persuasive.

\section{Result of Content Analysis}

In the Table 2, a summary of the results of content analysis based on the type of digital content marketing is attached.

Table 2. Summary Findings Based on The DCM Type

\begin{tabular}{lccccccccc}
\hline \multirow{2}{*}{ DCM Type } & \multicolumn{3}{c}{ Indonesia Travel } & \multicolumn{3}{c}{ Folk Indonesia } & \multicolumn{2}{c}{ Explore Indonesia } \\
\cline { 2 - 10 } & Post & Likes & Comment & Post & Likes & Comment & Post & Likes & Comment \\
\hline Informative & 7 & 40,083 & 353 & 5 & 80,832 & 547 & 6 & 22,967 & 94 \\
Persuasive & - & - & - & 44 & 678,54 & 2997 & 44 & 205,09 & 1415 \\
Both & 43 & 275,700 & 2520 & 1 & 12,700 & 77 & - & - & - \\
\hline
\end{tabular}

The results of this content analysis are in line with previous studies mention. Informative content has a negative effect on an engagement unless combined with persuasive content attributes (Shahbaznezhad et al., 2021; Voorveld et al., 2018). Informative content is intended to stimulate and facilitate customers' cognitive processing and the primary route of decision-making. As a result, because it requires more cognitive effort from the user, it will generate more active customer engagement, such as asking a question or commenting on a post. Informative content such as prices, availability, and product features reduce engagement when included in messages alone but increase engagement when combined with persuasive attributes (Islam et al., 2019; Lee et al., 2018).

\section{Discussion}

This study resulted in findings where persuasive content is digital content marketing with higher engagement when viewed from Instagram elements. In addition, the results of the identification of informative content in this study do not have a significant effect, even though @indonesiatravel has more followers than @folkindonesia and @exploreindonesia that show persuasive content. A study states that informative content negatively affects engagement unless combined with persuasive attributes (Lee et al., 2018). In the context of social media, a relationship between informative content and customer engagement (De Vries et al., 2012; Lee et al., 2018). When compared to persuasive content such as emotional and philanthropic content, informative content has been found to have a negative impact on levels of user engagement in the form of likes and comments (Lee et al., 2018). Posts containing brand information lead to lower engagement than persuasive content. The content presented by @indonesiatravel is informative content that has an engagement mix with persuasion. It was found that the results of engagement with consumers are lower than @folkindonesia and @exploreindonesia, which consistently present persuasive content. An experimental survey will be followed to determine which engagement most influenced the behavior planning trip.

In this study, there are several limitations. Firstly, limitations due to the COVID-19 pandemic affected the number of likes and comments in the content. During a pandemic, people feel a higher risk for 
all types of travel and avoid traveling to places they think are at moderate to high risk (Harrigan et al., 2017). It will impact consumer behavior planning trips because there will be many considerations in determining tourist destinations. Understanding and predicting customer engagement in the current tourism context becomes problematic because it has to adjust to government policies regarding travel document restrictions and requirements during a pandemic situation. Also, there are changes to the Instagram algorithm that might impact the data retrieval process. However, it will not discuss what the algorithm is like nowadays. In this study, the DCM only focuses on images. Future research may use moving images such as videos or reels as a new feature of longer duration Instagram.

\section{CONCLUSION}

This study is about the differences in digital content marketing that can contribute to tourism and marketing literature, especially studies on social media, Instagram. Also, contribute to consumer engagement concept literature in the tourism context. In addition, it can be a reference for company in the tourism sector to market their content by paying more attention to the type of content that is of interest to the public to attract public interest in the intended destination (destination branding).

\section{ACKNOWLEDGEMENT}

We would like to thank the official account of Kementerian Pariwisata Republik Indonesia (Indonesia Travel), Folk Indonesia, and Explore Indonesia for such great content to be used as an object in this study.

\section{REFERENCES}

Algharabat, R., Rana, N. P., Alalwan, A. A., Baabdullah, A., \& Gupta, A. (2020). Investigating the antecedents of customer brand engagement and consumer-based brand equity in social media. Journal of Retailing and Consumer Services, 53. https://doi.org/10.1016/j.jretconser.2019.01.016.

Alibage, A., \& Jetter, A. (2017). Drivers of consumers' emotional engagement with everyday products: An intensive review of the literature and an attempt to conceptualize the consumer-product interactions within the emotional design process. Student Research Symposium, 10. http://archives.pdx.edu/ds/psu/20217.

Alvarez-Milán, A., Felix, R., Rauschnabel, P. A., \& Hinsch, C. (2018). Strategic customer engagement marketing: A decision making framework. Journal of Business Research, 92, 61-70. https://doi.org/10.1016/j.jbusres.2018.07.017.

Barger, V., Peltier, J. W., \& Schultz, D. E. (2016). Social media and consumer engagement: a review and research agenda. Journal of Research in Interactive Marketing, 10(4), 268-287. https://doi.org/10.1108/JRIM-06-2016-0065.

Bianchi, C., \& Andrews, L. (2018). Consumer engagement with retail firms through social media: an empirical study in Chile. International Journal of Retail \& Distribution Management, 46(4), 364-385. https://doi.org/10.1108/IJRDM-02-2017-0035.

Brodie, R. J., Hollebeek, L. D., Jurić, B., \& Ilić, A. (2011). Customer engagement: Conceptual domain, fundamental propositions, and implications for research. Journal of Service Research, 14(3), 252271. https://doi.org/10.1177/1094670511411703.

Bu, Y., Parkinson, J., \& Thaichon, P. (2021). Digital content marketing as a catalyst for e-WOM in food

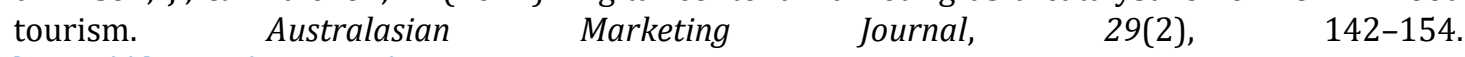
https://doi.org/10.1016/j.ausmj.2020.01.001.

Coelho, R. L. F., Oliveira, D. S. d., \& Almeida, M. I. S. d. (2016). Does social media matter for post typology? Impact of post content on Facebook and Instagram metrics. Online Information Review, 40(4), 458471. https://doi.org/10.1108/0IR-06-2015-0176.

Dabbous, A., \& Barakat, K. A. (2020). Bridging the online offline gap: Assessing the impact of brands' social network content quality on brand awareness and purchase intention. Journal of Retailing and Consumer Services, 53. https://doi.org/10.1016/j.jretconser.2019.101966.

De Vries, L., Gensler, S., \& Leeflang, P. S. (2012). Popularity of brand posts on brand fan pages: An investigation of the effects of social media marketing. Journal of Interactive Marketing, 26(2), 8391. https://doi.org/10.1016/j.intmar.2012.01.003.

Dinçer, S. (2018). Content Analysis in Scientific Research: Meta-Analysis, Meta-Synthesis, and Descriptive Content Analysis. Bartın University Journal of Faculty of Education, 7(1), 176-190. https://doi.org/https://dergipark.org.tr/en/pub/buefad/article/363159. 
Dolan, R., Conduit, J., Fahy, J., \& Goodman, S. (2016). Social media engagement behaviour: a uses and gratifications perspective. Journal of Strategic Marketing, 24(3-4), 261-277. https://doi.org/10.1080/0965254X.2015.1095222.

Dolan, R., Conduit, J., Frethey-Bentham, C., Fahy, J., \& Goodman, S. (2019). Social media engagement behavior: A framework for engaging customers through social media content. European Journal of Marketing, 53(10), 2213-2243. https://doi.org/10.1108/EJM-03-2017-0182.

Du Plessis, C. (2017). The role of content marketing in social media content communities. South African Journal of Information Management, 19(1), 1-7. https://doi.org/10.4102/sajim.v19i1.866.

Dwivedi, Y. K., Ismagilova, E., Hughes, D. L., Carlson, J., Filieri, R., Jacobson, J., ., \& Wang, Y. (2021). Setting The Future Of Digital And Social Media Marketing Research: Perspectives And Research Propositions. International Journal of Information Management, 59. https://doi.org/10.1016/j.ijinfomgt.2020.102168.

Eigenraam, A. W., Eelen, J., \& Verlegh, P. W. (2021). Let Me Entertain You? The Importance of Authenticity in Online Customer Engagement. Journal of Interactive Marketing, 54, 53-68. https://doi.org/10.1016/j.intmar.2020.11.001.

Fernandes, T., \& Moreira, M. (2019). Consumer brand engagement, satisfaction and brand loyalty: a comparative study between functional and emotional brand relationships. Journal of Product \& Brand Management, 28(2), 274-286. https://doi.org/10.1108/JPBM-08-2017-1545.

Filieri, R., Yen, D. A., \& Yu, Q. (2021). \#ILoveLondon: An exploration of the declaration of love towards a $\begin{array}{lllll}\text { destination on } \quad \text { Instagram. } & \text { Tourism }\end{array}$ https://doi.org/10.1016/j.tourman.2021.104291.

Gon, M. (2021). Local experiences on Instagram: Social media data as source of evidence for experience design. Journal of Destination Marketing \& Management, 19. https://doi.org/10.1016/j.jdmm.2020.100435.

Harrigan, P., Evers, U., Miles, M., \& Daly, T. (2017). Customer engagement with tourism social media brands. Tourism Management, 59, 597-609. https://doi.org/10.1016/j.tourman.2016.09.015.

Islam, J. U., Hollebeek, L. D., Rahman, Z., Khan, I., \& Rasool, A. (2019). Customer engagement in the service context: an empirical investigation of the construct, its antecedents and consequences. Journal of Retailing and Consumer Services, 50, 277-285. https://doi.org/10.1016/j.jretconser.2019.05.018.

Kannan, P. K. (2017). Digital marketing: A framework, review and research agenda. International Journal of Research in Marketing, 34(1), 22-45. https://doi.org/10.1016/j.ijresmar.2016.11.006.

Kim, B. K., \& Kim, K. O. (2020). Relationship between Viewing Motivation, Presence, Viewing Satisfaction, and Attitude toward Tourism Destinations Based on TV Travel Reality Variety Programs. Sustainability, 12(11), 4614. https://www.mdpi.com/735266.

Lee, D., Hosanagar, K., \& Nair, H. S. (2018). Advertising content and consumer engagement on social media: Evidence from Facebook. Management Science, 64(11), 5105-5131. https://doi.org/10.1287/mnsc.2017.2902.

Li, S. (2021). Linking servicescape and customer engagement: An investigation in the hotel context. International Journal of Hospitality Management, 94. https://doi.org/10.1016/j.jhm.2021.102880

Lujja, A., \& Özata, F. Z. (2017). The Consequences of Consumer Engagement in Social Networking Sites 1. Business and Economics Research Journal, 8(2), 275. https://www.ceeol.com/search/articledetail?id=562150,

Matikiti-Manyevere, R., \& Kruger, M. (2019). The role of social media sites in trip planning and destination decision-making processes. African Journal of Hospitality, Tourism and Leisure, 8(5), 1-10. https://www.ajhtl.com/uploads/7/1/6/3/7163688/article_3_vol_8_5_2019_cut.pdf.

Moran, G., Muzellec, L., \& Johnson, D. (2019). Message content features and social media engagement: evidence from the media industry. Journal of Product \& Brand Management, 29(5), 533-545. https://doi.org/10.1108/JPBM-09-2018-2014.

Pektas, S. Y., \& Hassan, A. (2020). The Effect of Digital Content Marketing on Tourists' Purchase Intention. $\begin{array}{llll}\text { Journal of Tourismology, } & \text { 6(1), }\end{array}$ https://dergipark.org.tr/en/pub/iuturizmoloji/issue/52515/690246.

Rietveld, R., van Dolen, W., Mazloom, M., \& Worring, M. (2020). What you feel, is what you like influence of message appeals on customer engagement on Instagram. Journal of Interactive Marketing, 49, 20 53. https://doi.org/10.1016/j.intmar.2019.06.003.

Shahbaznezhad, H., Dolan, R., \& Rashidirad, M. (2021). The role of social media content format and platform in Users' engagement behavior. Journal of Interactive Marketing, 53, 47-65. https://doi.org/10.1016/j.intmar.2020.05.001.

Shin, M., \& Back, K. J. (2020). Effect of cognitive engagement on the development of brand love in a hotel context. Journal of Hospitality \& Tourism Research, 44(2), 328-350. 
https://doi.org/10.1177/1096348019890055.

So, K. K. F., King, C., \& Sparks, B. (2014). Customer engagement with tourism brands: Scale development and validation. Journal of Hospitality \& Tourism Research, 38(3), 304-329. https://doi.org/10.1177/1096348012451456.

Taiminen, K., \& Ranaweera, C. (2019). Fostering brand engagement and value-laden trusted B2B relationships through digital content marketing: The role of brand's helpfulness. European Journal of Marketing, 53(9), 1759-1781. https://doi.org/10.1108/EJM-10-2017-0794.

Voorveld, H. A., Van Noort, G., Muntinga, D. G., \& Bronner, F. (2018). Engagement with social media and social media advertising: The differentiating role of platform type. Journal of Advertising, 47(1), 3854. https://doi.org/10.1080/00913367.2017.1405754.

Wang, P., \& McCarthy, B. (2021). What do people "like" on Facebook? Content marketing strategies used by retail bank brands in Australia and Singapore. Australasian Marketing Journal, 29(2), 155-176. https://doi.org/10.1016/j.ausmj.2020.04.008.

Zeng, B., \& Gerritsen, R. (2014). What do we know about social media in tourism? A review. Tourism Management Perspectives, 10, 27-36. https://doi.org/10.1016/j.tmp.2014.01.001. 